\title{
症例報告
}

\section{高 $\mathrm{Ca}$ 血症，四肢筋力低下で発症し，BHL を欠いた 筋サルコイドーシスの 1 例}

\author{
坂本 峻 ${ }^{1)} *$ 末永 浩一 ${ }^{1)}$ 笠間 周平 ${ }^{1)}$ \\ 木村 卓 ${ }^{1)}$ 芳川 浩男 ${ }^{1)}$
}

\begin{abstract}
要旨：症例は 73 歳男性である. 6 力月で進行する全身倦急感，四肢筋力低下，体重減少を主訴に入院した．血 液検査上では $\mathrm{Ca}, \mathrm{ACE}$, リゾチーム, SIL-2R, ビタミン $1,25(\mathrm{OH})_{2} \mathrm{D}$ が高值であった. 胸部 X 線および CT 上 BHL を認めず，気管支肺胞洗浄で， CD4/CD8 比の上昇を認めた. ${ }^{67}$ Ga-citrate シンチグラフィーでは大腿および肩〜 上腕部にかけて集積を認め, $T_{1}$ 強調画像でガドリニウム造影効果を認めたことより, 右大腿直筋より筋生検を行っ た. 筋生検で非乾酪性類上皮細胞肉芽腫を認めたため筋サルコイドーシスと診断した. 高 Ca 血症, 四肢筋力低下 で発症し, BHL を欠く筋サルコイドーシスはまれな症例である.
\end{abstract}

(臨床神経 2019;59:200-204)

Key words：高Ca 血症, 筋サルコイドーシス, 四肢筋力低下

はじめに

サルコイドーシスは多臟器に非乾酪性類上皮細胞肉芽腫を 生じる疾患であり, 霧視や湿疹, 不整脈, 顔面神経麻痺や聴 覚神経障害，高 $\mathrm{Ca}$ 血症，腎結石など多彩な症状を呈する全 身性疾患である ${ }^{1)}$.

今回我々は, 四肢筋力低下, 高 $\mathrm{Ca}$ 血症を来し，BHLを欠 き，筋生検で診断しえた，筋サルコイドーシスというまれな 1 例を経験したので文献的考察を含めて報告する。

\section{症例}

症例：73歳 男性

主訴：四肢筋力低下 食思不振

既往歴：特記すべき項目なし.

家族歴：類症なし.

内服薬：ドンペリドン $30 \mathrm{mg} /$ 日，メコバラミン $1.5 \mathrm{mg}$ 日.

現病歴：2016 年 4 月より四肢筋力低下を自覚し, 他院神 経内科で精査するも診断には至らなかった，その後も筋力低 下は進行した. 2016 年 10 月までの 6 カ月間で体重が $10 \mathrm{~kg}$ 減 少した，同月当科紹介され，入院した.

入院時現症：身長 $170 \mathrm{~cm}$, 体重 $54 \mathrm{~kg}$, 血圧 $148 / 71 \mathrm{mmHg}$, BMI 18.69，体温 $37.2^{\circ} \mathrm{C}$ であり，胸腹部に異常を認めず。リ ンパ節腫脤も認めなかった．神経学的所見については，意識
清明, 言語異常, 眼球運動異常, 顔面筋力異常, 両側難聴は 認めなかったが，飲食中のむせや咬合力の低下を自覚してい た. 徒手筋力検查 (右/左) は, 上腕二頭筋 $(4-/ 4-)$, 上腕 三頭筋 $(4-/ 4-)$, 手関節背屈 $(4-/ 4-)$, 手関節掌屈 $(4-/ 4-)$, 母指対立筋 $(4-/ 4-)$, 晹腰筋 $(4+/ 4+)$, 大腿四頭筋 $(3+/ 3+)$, 前脛骨筋 $(3+/ 3+)$, 大腿屈筋群 $(3+/ 3+)$, 腓腹筋 $(5 / 5)$, 握 力は右 $7 \mathrm{~kg}$ 左 $7 \mathrm{~kg}$ であった。 また, Barré垷候は陰性であり, 表在感覚 ·深部感覚, 腱反射は正常, 病的反射は陰性, 指鼻 試験, 踵㮏試験, 反復拮抗運動はともに正常, Romberg 徵候 除性であった，歩行時ふらつきあり，継ぎ足歩行不可，しゃ がみ立ち不可であった，自律神経症状は認めなかった．

入院時検查所見：血液検查では $\mathrm{Hb} 11.5 \mathrm{~g} / \mathrm{d} l$ と軽度の貧血 があった，総蛋白は $6.6 \mathrm{~g} / \mathrm{d} l$ と正常であったが，アルブミン $3.2 \mathrm{~g} / \mathrm{d} l, \mathrm{CK} 48 \mathrm{U} / l$ と低下していた. Ca $12.9 \mathrm{mg} / \mathrm{d} l$, 補正值で $13.7 \mathrm{mg} / \mathrm{d} l$, ビタミン $1,25(\mathrm{OH})_{2} \mathrm{D} 68.0 \mathrm{U} / l$ (正常值: 15 40), ACE (angiotensin converting enzyme) $56.2 \mathrm{U} / l$, リゾチーム $80 \mu \mathrm{g} / \mathrm{ml}, \quad \mathrm{sIL}-2 \mathrm{R} 5,452 \mathrm{U} / \mathrm{m} l$ と高值であったが PTHrP $1.0 \mathrm{pmol} / l$ 以下（正常值：20 80), PTH $9 \mathrm{pg} / \mathrm{ml}$ （正常值：10〜55）は 低值であった. 免疫学的検査では異常を認めなかった。 心電 図，胸部単純レントゲン，胸部 CT では異常を認めず，呼吸 機能検查は異常なかった.ツベルクリン反応は陰性であった。

入院後経過：筋力低下打よび体重減少から, 覀性疾患, 運 動ニューロン疾患等を鑑別に挙げ検査を行った，高 Ca 血症 に由来すると考えられる強い全身倇点感や繰り返す嘔気・嘔

\footnotetext{
*Corresponding author: 兵庫医科大学脳神経内科〔 ₹ 663-8501 兵庫県西宮市武庫川町 1-1〕

1) 兵庫医科大学脳神経内科

(Received December 4, 2018; Accepted February 5, 2019; Published online in J-STAGE on March 30, 2019)

doi: 10.5692/clinicalneurol.cn-001256
} 
吐があったため, 精査と並行して高 $\mathrm{Ca}$ 血症に対する治療を 行った。第 7 病日よりエルカトニンおよび生食点滴を行い, 第 12 病日には血清 $\mathrm{Ca}$ 值は $9.8 \mathrm{mmol} / l$ まで改善，また四肢筋 力も腸腰筋と大腿四頭筋を除き MMT $4+$ と改善した. しかし, 腸腰筋は $4+$ から $3+$ に低下し, 大腿四頭筋は $3+$ から改善が みられなかった。このことから，腸腰筋，大腿四頭筋の筋力 低下は，高 $\mathrm{Ca}$ 血症とは別の原因が考えられた。

高 $\mathrm{Ca}$ 血症の鑑別として, 悪性リンパ腫などの悪性疾患，肉 芽腫性疾患, 異所性 PTH 産生腫瘍, PTHrP 産生腫瘍などが 挙げられる。本例は, PTHrP が $1.0 \mathrm{pmol} / l$ 以下（正常值 : 20 〜80）と低下していたため, PTHrP 産生腫瘍の可能性は低い と考えられた。またPTHが低下しており異所性 PTH 産生腫 瘍など PTH 増多性疾患は否定的であった. 更にビタミン $1,25(\mathrm{OH})_{2} \mathrm{D}$ が上昇していたことから，乳癌，骨髄腫などの骨 融解性腫瘍も否定的と考えられ，以上より悪性リンパ腫等悪 性疾患やサルコイドーシスなどの肉芽腫性炎症性疾患が示唆 された。また ACE，リゾチーム， sIL-2R が高值であったこと からサルコイドーシスの可能性を第 1 に考えた。

次に, 悪性疾患やサルコイドーシスの病変検索のため胸腹 骨盤造影 CT を施行したところ，占拠性病変や造影効果は認

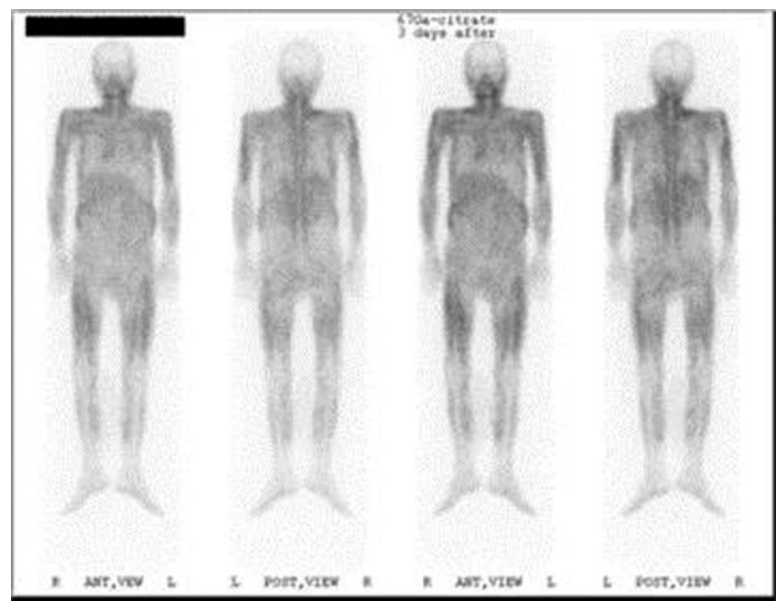

Fig. 1 67Ga-citrate scintigraphy. In $67 \mathrm{Ga}$-citrate scintigraphy, accumulation was recognized on the bilateral thigh and shoulder to upper arm.
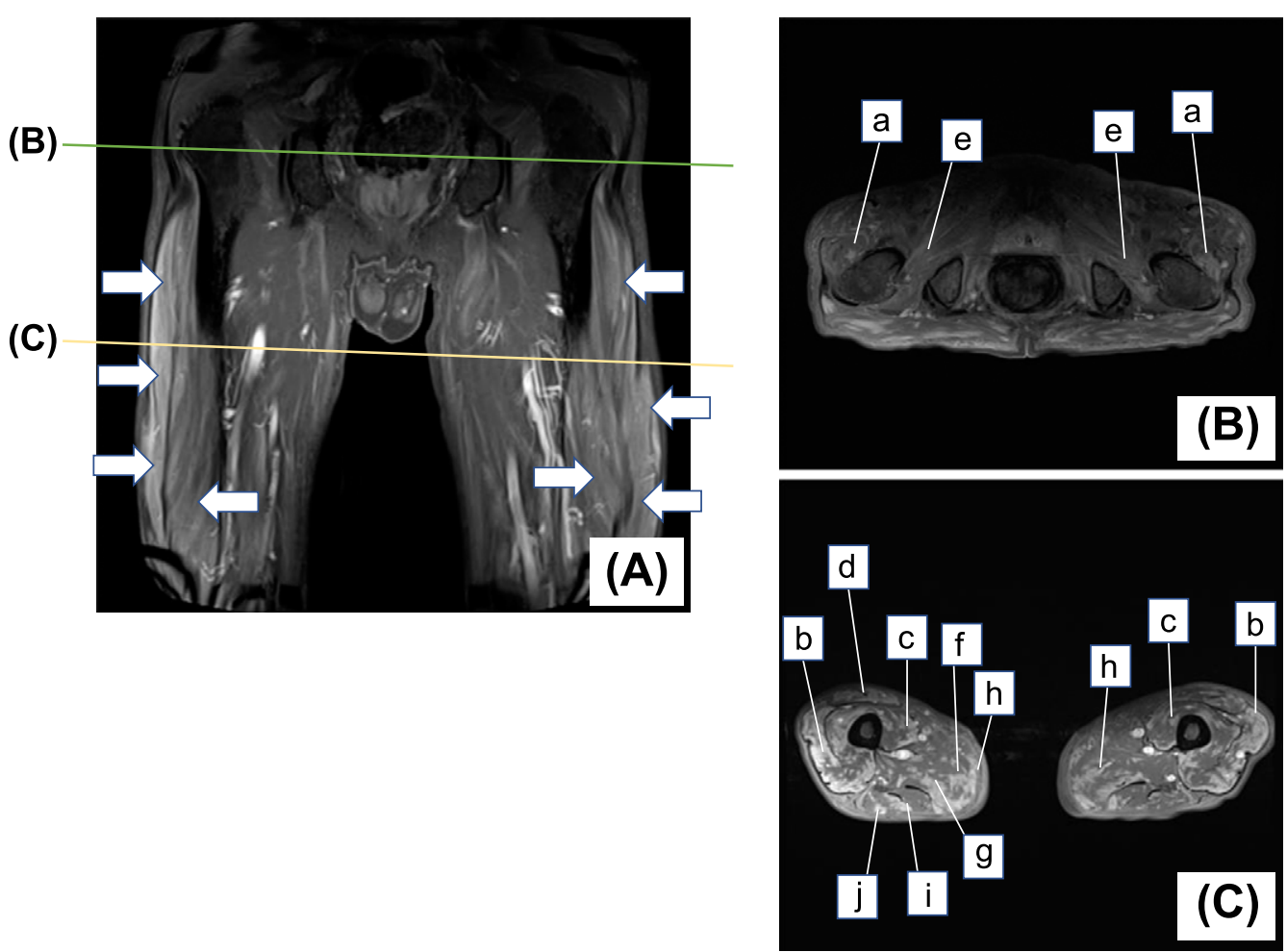

Fig. 2 Radiological findings.

Gadolinium enhanced magnetic resonance imaging (A: Coronal, B, C: Axial). In the figure of (A), many muscles of thigh show marked involvement (arrow). Cross sectional views display (B) and (C). In the $\mathrm{T}_{1}$ weighted image, the bilateral iliopsoas muscles (a), bilateral femoral quadriceps muscles (bilateral extensor muscles (b), right medial lateralis muscle (c), right rectus femoris (d)), bilateral pubic muscles (e), bilateral adductor longus muscles (f), right superior adductor muscle (g), right atrial muscle (h), right semimembranosus muscle (i), and the right semitendinosus muscle (j) show marked involvement. 
められず，また，サルコイド結節や肺門リンパ節腫脹も認め られなかった。

肺門リンパ節生検では，サルコイド結節などの所見は認め なかった、気管支肺胞洗浄検査では，リンパ球の上昇はみら れなかったものの CD4/CD8 比 4.3 （基準值 認めた。

${ }^{67} \mathrm{Ga}$-citrate シンチグラフィーを施行したところ，大腿およ び肩〜上腕部にかけて集積を認めた（Fig. 1). 大腿筋力につ いては, 血清 $\mathrm{Ca}$ 值の改善によっても筋力の改善がみられな かった部位であり，大腿 MRI を撮影したところ， $\mathrm{T}_{1}$ 強調画 像で両側腸腰筋，両側大腿四頭筋（画側外側広筋，右内側広 筋, 右大腿直筋), 両側恥骨筋, 両側長内転筋, 右大内転筋, 右薄筋, 右半膜様筋, 右半腱様筋にガドリニウム造影効果を 認めた（Fig. 2)。そこで，右大腿直筋より筋生検を行ったと ころ, 非乾酪性類上皮細胞肉芽腫および筋線維の大小不同を 認めた（Fig. 3).

サルコイドーシスの診断基準上 ${ }^{1)}$, 臓器に組織学的に非乾

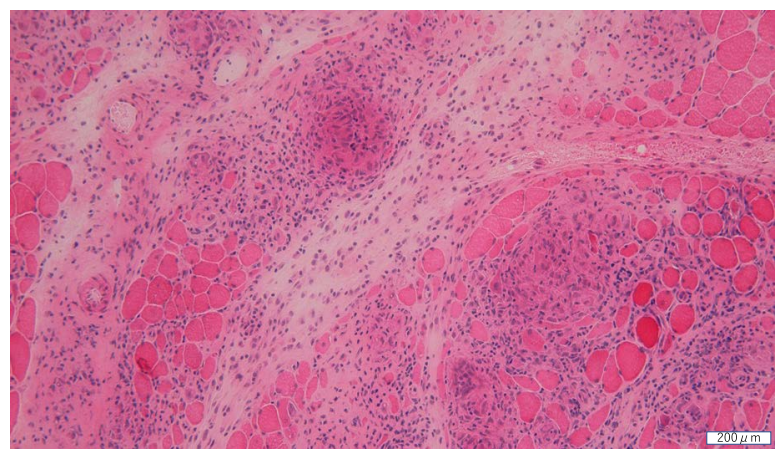

Fig. 3 Muscle pathology.

Muscle biopsy from the right rectus femoris showed scattered non-caseating granulomas and variation in muscle fiber diameter. Hematoxylin-eosin staining. (Bar $=200 \mu \mathrm{m}$ ).
酪性類上皮細胞肉芽腫を認め, 血清 ACE 活性高值, ${ }^{67} \mathrm{Ga}$-citrate シンチグラフィーにおける著明な集積所見, 気管支肺胞洗浄 検査でリンパ球増加または CD4/CD8 比高值, 血清あるいは 尿中 Ca 高值, といった項目を満たしたことから, サルコイ ドーシス組織診断群と診断した (Table 1). その後, サルコイ ドーシスの治療として第 40 病日よりステロイド $30 \mathrm{mg} /$ 日を 開始した。 この時点で, 血清 $\mathrm{Ca}$, 尿中 $\mathrm{Ca}$ はすでに正常化し ていたが, その後も正常範囲内で推移した。治療前, ビタミ ン $1,25(\mathrm{OH})_{2} \mathrm{D}$ は $85.0 \mathrm{U} / l, \mathrm{ACE}$ は $33.4 \mathrm{U} / l$ と上昇していたが, ステロイド治療開始後, ビタミン $1,25(\mathrm{OH})_{2} \mathrm{D}$ は $13.7 \mathrm{U} / l, \mathrm{ACE}$ は $20.9 \mathrm{U} / l$ と著明に減少した. MMTも腸腰筋, 大腿四頭筋で 3 から 5 に改善した。第 67 病日にステロイドを $20 \mathrm{mg} /$ 日に 減量した時点で, 自宅退院した（Fig. 4).

\section{考察}

サルコイドーシスは 1869 年に本症の皮膚病変が英国の内 科医 Jonathan Hutchinson らによって報告された疾患である. 典型的には若年女性に好発し, BHL および肺野病変, 皮膚, 関節および眼症状にて初発することが多く, 約 $90 \%$ が肺病変 を形成するといわれている. 我が国の有病率は人口 10 万人当 たり 7.5〜9.3 であり，好発年齢は 20～30 代， 50～60 代の 2 峰性を示す ${ }^{1)}$.

筋サルコイドーシスについては, サルコイドーシス症例の 50〜80\%に筋組織内に類上皮細胞肉芽腫が検出されるが，症 候性の筋サルコイドーシスの頻度は 0.5 2.3\%と稀であると 報告されている。 また, 症候性のものは腫瘤型, 急性・亜急 性筋炎型, 慢性ミオパチー型に分類される ${ }^{2)}$. 2012 年に熊本 らは, 年齢, 性別, サルコイドーシスの発症年齢, 筋症状の 発症年齢, 仮性肥大は 3 型間に優位差はないが, 急性・亜急 性筋炎型, 慢性ミオパチー型では, 左右対称性かびまん性の 四肢近位筋力低下や筋萎縮を認めると報告している ${ }^{3)}$. 急性,

Table 1 Sarcoidosis diagnostic criteria.

\footnotetext{
【Histological diagnosis group】

Sarcoidosis is confirmed when biopsy specimens from any organs of the whole body demonstrate non-caseating epithelioid granulomas, and either of granulomas derived from other known causes or local sarcoid reaction is excluded.

It is also necessary to carefully evaluate characteristic laboratory findings and other organ involvement to confirm the diagnosis.

【Clinical diagnosis group】

Although biopsy specimens do not demonstrate non-caseating epithelioid granulomas, sarcoidosis is diagnosed clinically when 1) clinical findings are strongly suggestive of this disease in two or more of the three organs: respiratory organ, eye and heart and 2) two or more of the five characteristic laboratory findings as follows are positive.

Characteristic laboratory findings:

1) Bilateral hilar lymph node swelling

2) High serum angiotensin converting enzyme value or high serum lysozyme value

3) High serum soluble interlukin-2 receptor value

4) Increased uptake on Gallium-67 citrate scintigraphy or fluorine-18-fluorodeoxyglucose (18F-FDG) positron emission tomography (PET)

5) Bronchoalveolar lavage test demonstrates an increased lymphocyte ratio or an elevated CD4 to CD8 ratio to above 3.5
}

Source: Japan Society of Sarcoidosis and other Granulomatous Disorders. Diagnostic Standard and Guideline for Sarcoidosis-2015. 


\section{(A)}
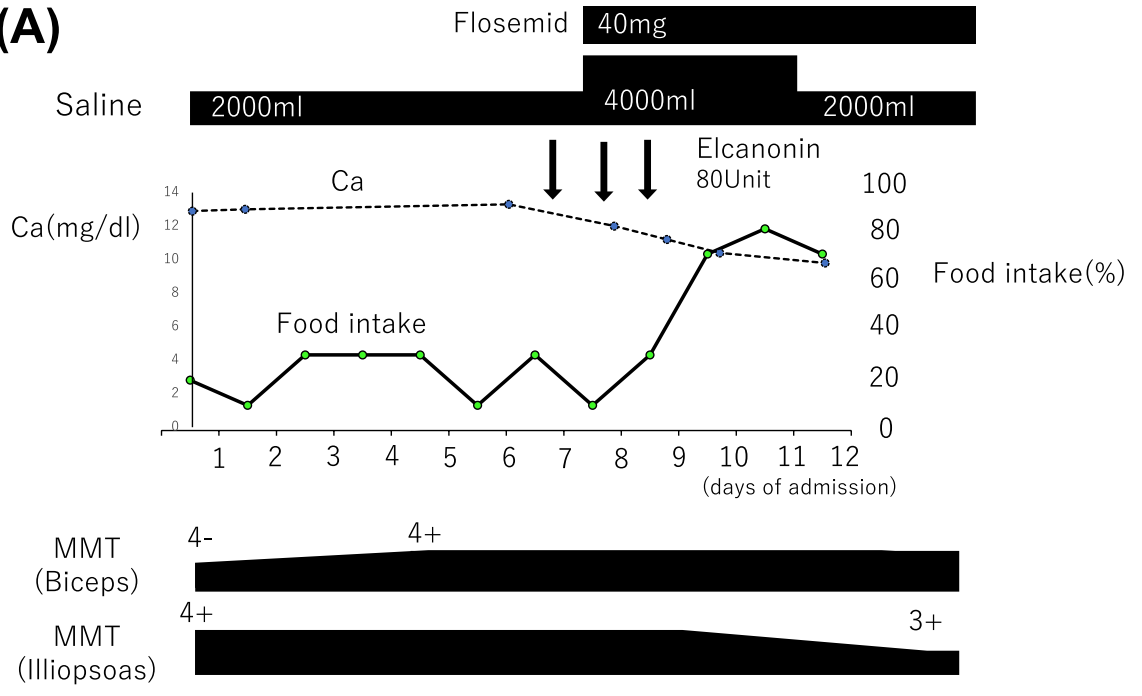

(B)

Days of admission

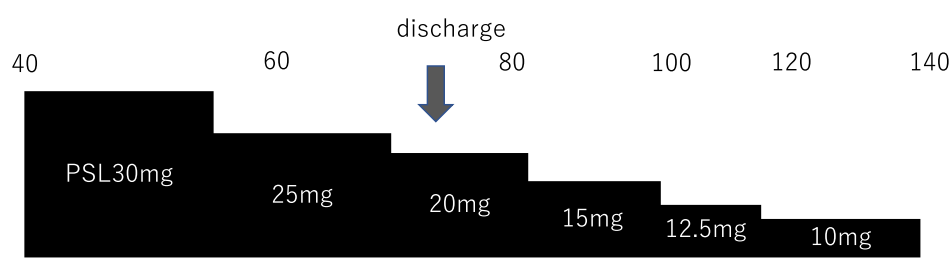

$\mathrm{Ca}$

$(\mathrm{mg} / \mathrm{dl})$

11.1

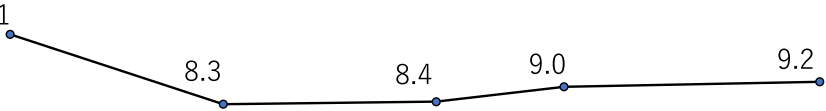

Vit1.25(OH) $)_{2} \mathrm{D}$

$(\mathrm{U} / \mathrm{I})$

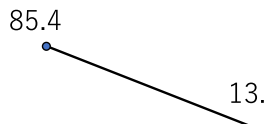

13.7

13.1

18.8

40.1

ACE

34.4

20.9

$<0.3$

MMT

(Illiopsoas)

3

5

Fig. 4 Clinical course.

(A) Clinical course (1). Serum Ca were normalized by intravenous drip of Erucatonin , physiological saline and furosemide. And food intake increased significantly. After serum Ca was normalized, the upper limb improved to 4+, while illiopsoas decreased to MMT 3+. (B) Clinical course (2). As a course of treatment, we started steroids from day 40. Then both blood and urinary $\mathrm{Ca}$ have been in the normal range. Also, at the stage where steroid decreased $25 \mathrm{mg}$, active vitamin $\mathrm{D}$ decreased to normal level. MMT also became full at the same time. On day 67 the patient was discharged.

亜急性筋炎と慢性ミオパチー型は発症パターン以外では病理 所見や臨床症状も似ており，区別が困難である ${ }^{4)}$ 。本症例も 筋肉内腫瘤を触知せず，四肢近位の筋力低下や筋萎縮を認め ており，いずれかの型に一致すると考えられる。また，サル コイドーシスの中で, BHLを来さないものは全体の 10～20\% と低頻度であり ${ }^{5)}$, また, 高 $\mathrm{Ca}$ 血症の合併については, 本邦 では 5.1〜 $14.3 \%$ と比較的低く, 特に血清 $\mathrm{Ca}$ 濃度が $11.0 \mathrm{mg} / \mathrm{d} l$ を超える事は極めて稀とされている ${ }^{6)}$.

更に，BHLを欠き，高 Ca 血症を合併した例は非常に稀で あり，検索し得た範囲では，1999 年の岡嶋らによる報告 1 例
のみであった ${ }^{7)}$ 。本症例では全身倦忠感が主訴で，血中 $\mathrm{Ca}$, ACEの高值を認め, 肺門リンパ節腫脹はなく, ステロイドで 軽快している点が類似している。岡嶋らの報告では，気管支 鏡生検で確定診断しているが，我々の症例では気管支鏡生検 では確定できず，筋生検で確定診断した。

サルコイドーシスに拈ける高 $\mathrm{Ca}$ 血症の機序は, マクロ ファージや類上皮細胞肉芽腫が産生する $1 \alpha$-hydroxlase によ る 25(OH)D から活性型ビタミン Dへの変換のえ進が, 主た る病態と考えられてきた ${ }^{8)}$. 本例でも, 活性型ビタミン D は $68.0 \mathrm{U} / l$ （正常範囲 15～40 U/l） と高值を示していた. 
また，サルコイドーシスは，未知の抗原に対する Th1 型肉 芽腫反応と考えられており，抗原に遭遇したマクロファージ は過㮃な Th1 型免疫反応を生じ, 肉芽種の主要な構成要素と なる ${ }^{9)}$. BHL については, 原因抗原が肺から侵入し, 胸郭内 の所属リンパ節を侵し, このため両側リンパ節が腫脹すると の説明もなされている ${ }^{10) 11)}$ が, BHLを伴いやすい本疾患患者 の臨床的特徵や患者背景などについては明らかではなく，本 例でBHLを欠いた理由は不明である。

本例は，BHL を欠き，高 $\mathrm{Ca}$ 血症を伴う四肢筋力低下患者 であり，当初高 $\mathrm{Ca}$ 血症に由来する症状と考え，高 $\mathrm{Ca}$ 血症を きたす原疾患の鑑別に留意して各種検査を行った。高 Ca 血 症の治療に伴う筋力改善について, 両側腸腰筋, 大腿四頭筋 の筋力改善が他の部位と解離があるという臨床経過に着目 し，また高 $\mathrm{Ca}$ 血症についてサルコイドーシスの鑑別が必要 との結論から，大腿直筋生検等を行い，筋サルコイドーシス の診断を確定し得た. 鑑別にあたっては, 丁寧な経過観察や, 臨床所見の吟味を含め診断を行う必要があると考えた。

$$
\text { おわりに }
$$

四肢筋力低下を主訴とし，高 Ca 血症を呈し，BHL を認め なかった筋サルコイドーシスの 1 例を経験した。本例は極め て稀な例であるが，サルコイドーシスは多彩な症状を呈する ことから，鑑別に特に留意する必要があると考えた

本論文の要旨は, 平成 29 年 12 月 2 日に開催された日本内科学会近 畿支部主催第 218 回近畿地方会で発表した.

※著者全員に本論文に関連し, 開示すべき COI 状態にある企業, 組 織, 団体はいずれも有りません。

\section{文献}

1）サルコイドーシス診断基準改訂委員会. サルコイドーシスの 診断基準と診断の手引き一2006. 日サ会誌 2007;27:89-102.

2）辰野健太郎, 中村聖香, 朝山知子ら。筋症状のみを呈した慢 性ミオパチー型筋サルコイドーシスの一例。臨床神経 2014;54:313-316.

3）熊本俊秀, 竹丸 誠, 姫野隆洋ら. 慢性ミオパチー型筋サル コイドーシス。日サ会誌 2012;32:33-37.

4) Jamal MM, Cilursu AM, Hoffman EL, et al. Sarcoidosis presenting as acute myositis. Report and review of the literature. J Rheumatol 1988;15:1868-1871.

5）森本泰介, 吾妻安良太, 阿部信二ら。2004 年サルコイドー シス疫学調査. 日茾会誌 2007;27:103-108.

6）篠崎一哉, 古家大祐, 繁田幸男ら。著明な高 Ca 血症を呈した 肺サルコイドーシスの一例. 日内分泌会誌 1994;70:503-510.

7）岡嶋克則, 高田幸浩, 水谷哲郎ら. BHL を認めず，著明な 高カルシウム血症を認めたサルコイドーシスの 1 例. 日呼吸 会誌 1999;37:214-217.

8) Sharma OP. Vitamin D, calcium and sarcoidosis. Chest 1996; 109:535-539

9）澤幡美千瑠, 杉山幸比古. 疫学的視点からみたサルコイドー シスの病態と病因（総説）。日サ会誌 2015;35:17-25.

10) Muller-Quernheim J. Sarcoidosis: immunopathogenetic concepts and their clinical application. Eur Respir J 1998;12:716-738.

11) Corrin B, Nicholson AG, Dewar A. Pathology. In: Mitchell D, Wells A, Spiro S, Moller D, et al. Saecoidosis. London: Hodder Arnold; 2012. p. 41-47.

\title{
Abstract \\ A case of muscle sarcoidosis with hypercalcemia, lower limb muscle strength and without bilateral hilar lymphadenopathy
}

\author{
Shun Sakamoto, M.D. ${ }^{1)}$, Koichi Suenaga, M.D., Ph.D. ${ }^{1)}$, Shuhei Kasama, M.D., Ph.D. ${ }^{1)}$, \\ Takashi Kimura, M.D., Ph.D. ${ }^{1)}$ and Hiroo Yoshikawa, M.D., Ph.D. ${ }^{1)}$ \\ ${ }^{1)}$ Department of Internal Medicine, Division of Neurology, Hyogo College of Medicine
}

A 73-year-old man was hospitalized with complaints of general malaise, limb muscle weakness and weight loss progressing in 6 months. Ca, ACE, lysozyme, sIL-2R, vitamin $1.25 \mathrm{D}$ was high in the blood test. Bilateral hilar lymphadenopathy on $\mathrm{CT}$ were not recognized, and $\mathrm{CD} 4 / \mathrm{CD} 8$ ratio increased by bronchoalveolar lavage. In the ${ }^{67}$ Ga-citrate scintigraphy, accumulation was observed on the thigh and shoulder to the upper arm bilaterally. A muscle biopsy was performed from the right femoris muscle where the gadolinium contrast effect in the $T_{1}$ weighted image was observed. As muscle biopsy revealed non-toxic epithelial cell granulomas, he was diagnosed as muscle sarcoidosis. Even if bilateral hilar lymphadenopathy is not observed, muscle sarcoidosis should be considered in patients developed with hypercalcemia and limb muscle weakness.

Key words: hypercalcemia, muscle sarcoidosis, muscle weakness 